\title{
Effects of Cardiac Glycosides on Renal Tubular Transport of Calcium, Magnesium, Inorganic Phosphate, and Glucose in the Dog*
}

\author{
Sherman Kupfer $†$ and Jonah D. Kosovsky \\ (From the Department of Medicine, The Mount Sinai Hospital, New York, N. Y.)
}

It has now been established that the cardiac glycosides, and their aglycones, inhibit the cellular transport of sodium and potassium in a variety of tissues (1-9). In respect to the kidney, a number of studies have shown that when these drugs are infused into one renal artery, the resultant inhibition of renal tubular function is manifested by a profound ipsilateral natriuresis, chloruresis, and diuresis (10-12). Cade, Shalhoub, Cannessa-Fischer, and Pitts (13) observed that this renal response in the dog was associated with a diminished capacity to excrete potassium and to maintain a steep hydrogen ion concentration gradient. These authors noted a slight reduction, of uncertain significance, in inorganic phosphate reabsorption in several of their experiments.

Cardiac glycosides also affect transport systems other than that for sodium and potassium. These include para-aminohippurate uptake in renal cortical slices (14), iodide uptake in thyroid slices (15), and hexose transport in the small intestine of the frog (16). These particular transport systems, however, have all been shown to depend primarily on either potassium or sodium transport. In mammalian small intestinal sacs, inorganic phosphate and glucose transport were observed to be dependent on sodium, but the transport of calcium was not (17). The results of studies in frog ventricle in which transport of both calcium and sodium was measured simultaneously have been interpreted as indicative of

\footnotetext{
* Submitted for publication December 11, 1962; accepted March 4, 1965.

This work was supported by U. S. Public Health Service grants HE 04845 and AM 07685.

$\dagger$ Address requests for reprints to Dr. Sherman Kupfer, The Mount Sinai Hospital, Fifth Avenue and One Hundredth Street, New York 29, N. Y.
}

a competitive relationship between these ions (18).

In the experiments to be described, the direct effects of two cardiac glycosides on renal tubular transport of calcium, magnesium, inorganic phosphate, and glucose in the dog were studied, and their relationship to sodium transport was assessed. In these experiments, infusion of a small quantity of a solution containing either strophanthin kombé or digoxin into one renal artery was followed by enhanced excretion of calcium, magnesium, and inorganic phosphate by the ipsilateral kidney, whereas no changes in renal function were observed in the contralateral kidney that served as a control. In several experiments in which a large load of glucose was then infused intravenously, no measurable differences in the maximal rate of reabsorption of glucose for each kidney were detected.

\section{Methods}

Protocol $A$. A total of 25 experiments comprise this group. Female mongrel dogs weighing 12 to $27 \mathrm{~kg}$ were anesthetized with sodium pentobarbital, $30 \mathrm{mg}$ per $\mathrm{kg}$. Five hundred to $1,000 \mathrm{ml}$ of isotonic sodium chloride solution, containing an additional $4 \mathrm{mEq}$ per $\mathrm{L}$ potassium, $5 \mathrm{mEq}$ per $\mathrm{L}$ calcium, and $1.5 \mathrm{mEq}$ per $\mathrm{L}$ magnesium as chloride salts, was administered intravenously following induction of anesthesia and during the course of the preparatory surgery. A small suprapubic incision was made through which both ureters were isolated and catheterized. This permitted simultaneous collection of timed urine samples from each kidney. The origin of the left renal artery was identified after a retroperitoneal dissection through the left flank. A curved hollow-bore, 30-gauge needle attached to a long length of no. 10 polyethylene tubing was then inserted into the left renal artery. Clotting in this needle was prevented by a constant infusion of isotonic sodium chloride at 0.3 to $0.5 \mathrm{ml}$ per minute.

A cannula with stylus was inserted into the carotid artery to facilitate appropriately timed blood sampling. A priming solution containing creatinine and para-amino- 
hippurate for the estimation of glomerular filtration rate and renal plasma flow, respectively, was then administered intravenously, followed by another solution containing these substances at a rate designed to maintain the plasma concentration at nearly steady levels. After a suitable interval for equilibration, two or three premedication clearance periods of either 10 or 20 minutes, depending on the urine flow, were obtained simultaneously from each kidney. Without altering the rate of infusion into the renal artery ( 0.3 to $0.5 \mathrm{ml}$ per minute), the isotonic saline solution was then replaced with one containing either 0.05 to $0.08 \mathrm{mg}$ per $\mathrm{kg}$ strophanthin kombé or digoxin diluted in a volume of isotonic saline that was infused completely within 30 to 60 minutes. The isotonic sodium chloride solution was then restarted and continued until the end of the experiment. Since digoxin had to be dissolved in $1 \mathrm{ml}$ of $95 \%$ ethanol, the effects of an intrarenal arterial infusion of this quantity of ethanol diluted in $20 \mathrm{ml}$ of isotonic sodium chloride were observed in two experiments for as long as 4 hours after the termination of the infusion. No alterations in renal functions were noted.

To compare the effects of the cardiac glycosides with other natriuretic agents, three experiments were performed in which 0.6 to $0.9 \mathrm{mg} \mathrm{Hg}$ per $\mathrm{kg}$, as sodium mercaptomerin or chlomerodrin, was infused into the renal artery instead of the glycosides.

Protocol $B$. In this group of ten studies (eight cardiac glycosides, two mercurials) the initial surgical and experimental procedures were identical with those described in protocol A. After intrarenal arterial administration of the drug, phosphate as buffered sodium phosphate ( $\mathrm{pH}$ 7.4) was slowly infused intravenously to raise the plasma inorganic phosphate content in a stepwise manner. This phosphate solution was infused until the end of the experiment. After a number of observations had been made at high plasma phosphate concentrations, sufficient glucose was injected intravenously to raise and maintain the plasma glucose concentration above the threshold for complete tubular reabsorption.

Analytic methods. Plasma creatinine concentrations were determined on 1:30 tungstate filtrates. The intensity of the color development in these filtrates and in appropriate dilutions of the urine following the addition of an alkaline picrate solution was read in a Coleman Universal spectrophotometer at $505 \mathrm{~m} \mu$ and compared to that of similarly prepared standard solutions. Paraaminohippurate was determined by the method described by Smith and associates (19). Sodium and potassium were measured by flame photometry using lithium for internal standardization. The Kingsley and Robnett (20) method was used to determine calcium. Recoveries from both urine and plasma by this method ranged from 93 to $96 \%$. Magnesium was determined by a modification of the titan yellow dye method (21). Trichloroacetic acid filtrates of plasma were prepared in a 1:5 dilution, together with appropriate dilutions of the urine, so that the resultant concentration of magnesium ranged from 0.16 to $0.66 \mathrm{mEq}$ per $\mathrm{L}$. One $\mathrm{ml}$ of $100 \mathrm{mg}$ per 100
TABLE I

Control periods

[mean differences: noninfused kidney (control) minus infused kidney (experimental) ]*

\begin{tabular}{rcccc}
\hline \hline Function & $\mathrm{N}$ & \multicolumn{4}{c}{ Mean difference $\pm \mathrm{SD} \dagger$} & $\mathrm{p}$ \\
\hline $\mathrm{V}$ & 60 & $-0.007 \mathrm{ml} / \mathrm{min} \pm 0.37$ & $>0.9$ \\
$\mathrm{GFR}$ & 60 & 0.15 & $\mathrm{ml} / \mathrm{min} \pm 2.6$ & $>0.9$ \\
$\mathrm{C}_{\mathrm{PAB}}$ & 60 & 0.15 & $\mathrm{ml} / \mathrm{min} \pm 7.2$ & $>0.9$ \\
$\mathrm{U}_{\mathrm{NaV}}$ & 60 & -11.7 & $\mu \mathrm{Eq} / \mathrm{min} \pm 27.8$ & $0.6-0.7$ \\
$\mathrm{UCB}_{\mathrm{CB}}$ & 60 & 0.2 & $\mu \mathrm{Eq} / \mathrm{min} \pm 1.2$ & $0.8-0.9$ \\
$\mathrm{U}_{\mathrm{Mg}} \mathrm{V}$ & 51 & -0.6 & $\mu \mathrm{Eq} / \mathrm{min} \pm 1.1$ & $0.5-0.6$ \\
$\mathrm{U}_{\mathrm{PV}}$ & 30 & 0.05 & $\mu \mathrm{moles} / \mathrm{min} \pm 0.6$ & $>0.9$
\end{tabular}

* V = rate of urine flow; GFR = glomerular filtration rate; $\mathrm{C}_{\mathrm{PAH}}=$ clearance of para-aminohippurate; $\mathrm{U}_{\mathrm{Na}} \mathrm{V}$, $\mathrm{U}_{\mathrm{Ca}}, \mathrm{U}_{\mathbf{M g}_{\mathrm{g}} \mathrm{V}}$, and $\mathrm{U}_{\mathrm{PV}}=$ urinary excretion of $\mathrm{Na}, \mathrm{Ca}, \mathrm{Mg}$, and $\mathrm{P}$.

$\dagger$ Standard deviation of the distribution.

$\mathrm{ml}$ polyvinyl alcohol solution was added to $1.0 \mathrm{ml}$ of plasma filtrate or urine dilution. To this mixture were added serially, $1.0 \mathrm{ml}$ of freshly prepared titan yellow (10 $\mathrm{mg}$ per $100 \mathrm{ml}$ ) and $1.0 \mathrm{ml}$ of $15 \%$ sodium hydroxide. The final color was read in a Junior Coleman spectrophotometer at $540 \mathrm{~m} \mu$ and compared to that of standards similarly prepared in duplicate. Recoveries in both urine and plasma ranged from 91 to $96 \%$. Recently, we have had the opportunity to check the values for calcium and magnesium in both urine and plasma, as determined by these methods, with those obtained by atomic absorption spectometry $(22,23)$ and have found them to be comparable. Chloride was measured with a Cotlove electrometric titrator (24), phosphate by the method of Fiske and Subbarow (25), and glucose by a modification of the method of Nelson (26).

\section{Results}

Effects of operative manipulation and intrarenal arterial infusion of saline. The data obtained during the initial control periods were analyzed statistically to determine if the operative manipulations and infusion of isotonic saline solution into one renal artery had of themselves any significant effect on the infused (experimental) kidney. In every control period, a mean paired difference (noninfused kidney minus experimental kidney) was calculated for each parameter. The mean of each mean paired difference was tested to determine whether it differed significantly from zero. The results of these calculations, tabulated in $\mathrm{Ta}$ ble I, showed no significant differences between the two kidneys before the administration of cardiac glycoside.

Alteration in renal hemodynamics during the intrarenal arterial administration of cardiac glycosides. During the unilateral intrarenal arterial 
infusion of cardiac glycoside to the experimental kidney, little or no changes in glomerular filtration rate (GFR) and clearance of para-aminohippurate $\left(\mathrm{C}_{\mathrm{PAH}}\right)$ on the noninfused side were noted. In 13 of 20 experiments, $\mathrm{GFR}$ and $\mathrm{C}_{\mathrm{PAB}}$ in the infused kidney showed little change during the infusion of the drug; in the remaining seven experiments, GFR and $\mathrm{C}_{\mathrm{PAH}}$ in the experimental kidney decreased while the drug was being infused into the renal artery. In these 20 experiments (23 paired observations) the mean differences in GFR and $\mathrm{C}_{\mathrm{PAH}}$ between each kidney (noninfused kidney minus infused kidney) were $4.8 \mathrm{ml}$ per minute $\pm 4.43^{1}(\mathrm{p}=0.3)$ and $4.9 \mathrm{ml}$ per minute $\pm 3.05(0.2>\mathrm{p}>0.1)$.

Alterations in renal function following the intrarenal arterial infusion of cardiac glycosides. In the seven experiments mentioned above, in which GFR and $\mathrm{C}_{\mathbf{P A H}}$ in the experimental kidney did fall while the cardiac glycoside was being infused, the GFR and $\mathrm{C}_{\mathbf{P A B}}$ returned to or toward initial levels when the drug infusion was terminated. Analyses from all experiments revealed that the mean differences in GFR and $\mathrm{C}_{\mathbf{P A B}}$ between each kidney (noninfused kidney minus in-

1 Standard deviation of the distribution.
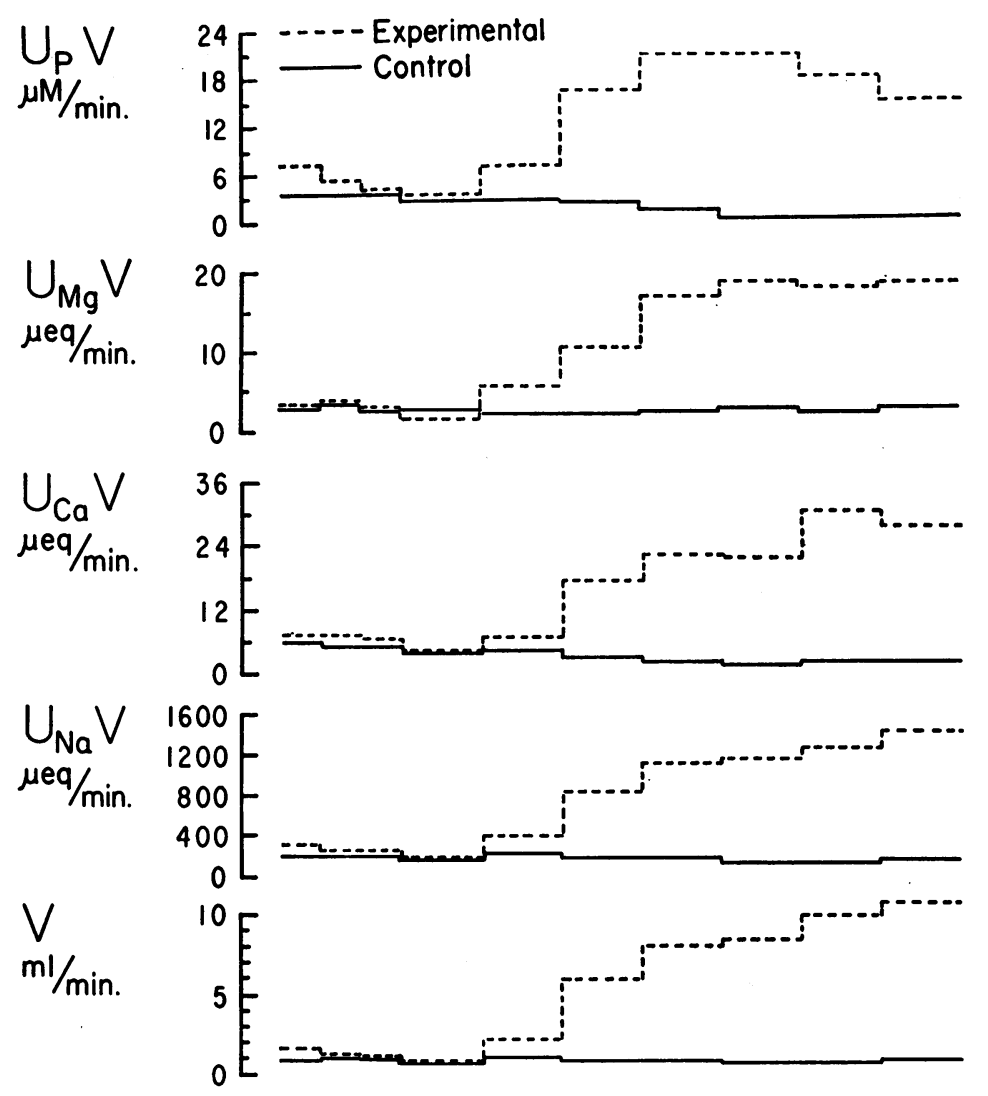

G.F.R.

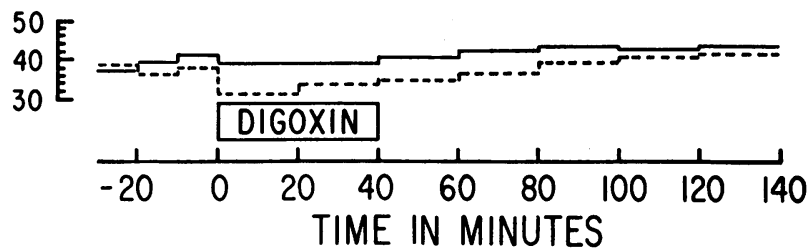

Fig. 1. EFfects of UNILATERAL RENAL ARTERIAL ADMINISTRation of DIGOXIN (0.05 MG PER KG) ON RENAL FUNCTION AND ELECTROLYTE EXCRETION. $\mathrm{U}_{\mathrm{P}} \mathrm{V}, \mathrm{U}_{\mathrm{Mg}} \mathrm{V}, \mathrm{U}_{\mathrm{Ca}_{\mathrm{a}} \mathrm{V}}$, and $\mathrm{U}_{\mathrm{Na}} \mathrm{V}=$ urinary excretion of $\mathrm{P}, \mathrm{Mg}, \mathrm{Ca}$, and $\mathrm{Na}$; $\mathrm{V}=$ rate of urine flow; and $\mathrm{GFR}=$ glomerular filtration rate. 

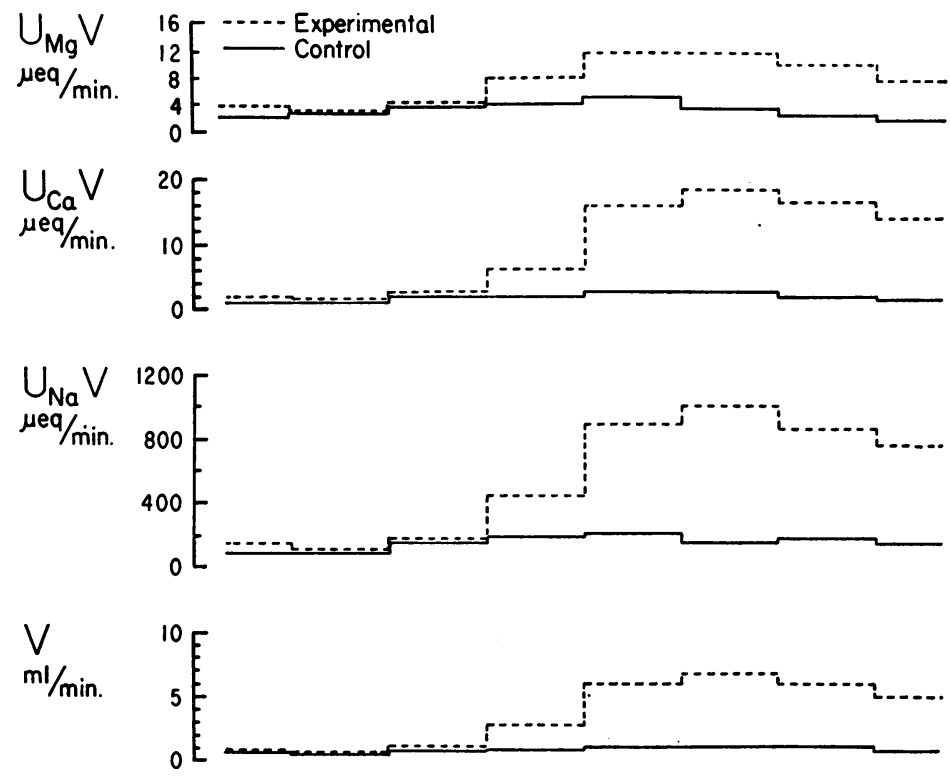

G.F.R. $\mathrm{ml} / \mathrm{min}$.

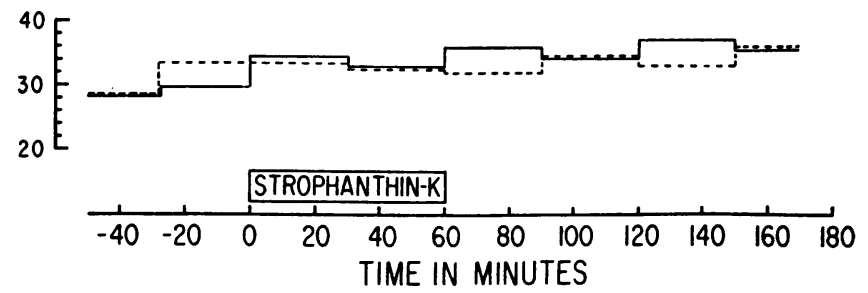

Fig. 2. EFfects of Unilateral RENal ARTERIAL administration of STROPHANTHIN KOMBE ( 0.05 MG PER KG) ON RENAL FUNCTION AND ELECTROLYTE EXCRETION.

fused kidney) 100 minutes after the start of the drug infusion were $3.0 \mathrm{ml}$ per minute $\pm 4.5(0.6$ $>\mathrm{p}>0.5)$ and $3.8 \mathrm{ml}$ per minute $\pm 5.0(0.5>$ $\mathrm{p}>0.4)$.

In three experiments there was some reduction in hemodynamic functions of both kidneys, presumed to be due to prolonged anesthesia and multiple blood sampling.

An experiment in which digoxin, $0.05 \mathrm{mg}$ per $\mathrm{kg}$, was infused during a 40-minute interval is illustrated in Figure 1. Changes in urine flow and sodium excretion were noted during the final minutes in which the drug was being given. Thereafter, the experimental kidney exhibited progressive increases in urine flow from 2.3 to $10.6 \mathrm{ml}$ per minute and sodium excretion from 250 to $1,420 \mu \mathrm{Eq}$ per minute.

In the experiment illustrated in Figure 2, strophanthin kombé, $0.05 \mathrm{mg}$ per $\mathrm{kg}$, was infused for 1 hour. Small increments in urine flow and sodium excretion in the infused kidney were noted during the last period of drug infusion. These increments reached peak values of $6.5 \mathrm{ml}$ per minute and $950 \mu \mathrm{Eq}$ per minute at 100 to 120 minutes after commencement of the unilateral infusion into the renal artery.

Effects of cardiac glycosides on calcium and magnesium excretion. As shown in Figures 1 and 2 , the urinary excretion of calcium and magnesium from each kidney did not differ significantly during the premedication infusion periods. After infusion with digoxin or strophanthin kombé in the dosages specified, the excretion of these divalent cations by the infused kidney increased significantly.

In the twenty experiments with cardiac glycosides in this series, mean calcium excretion during premedication periods from both kidneys and from the contralateral control kidney during and after drug infusion was $4.32 \mu \mathrm{Eq}$ per minute 

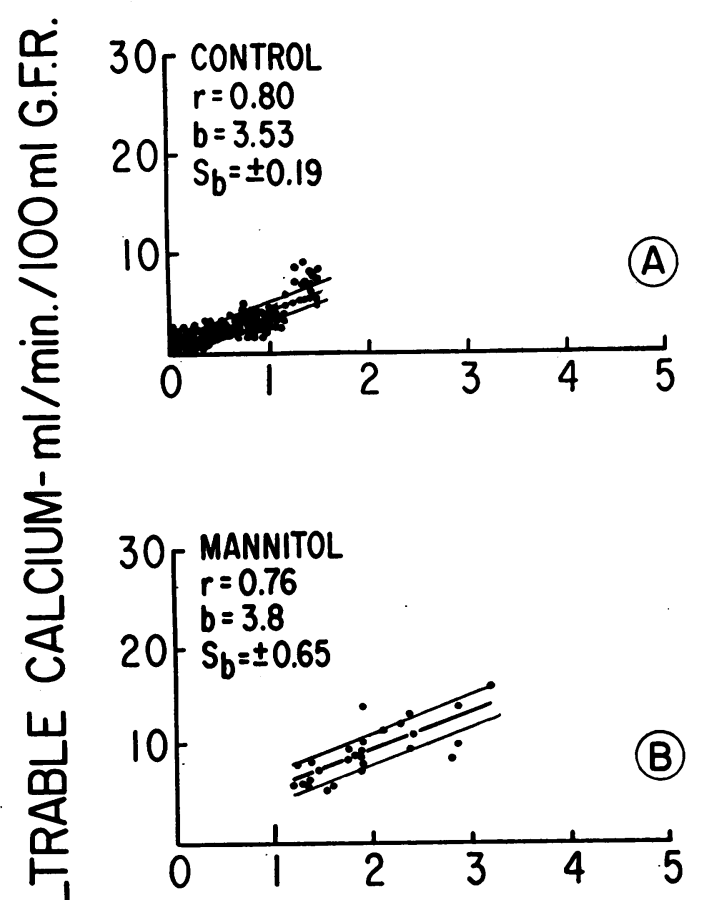

J
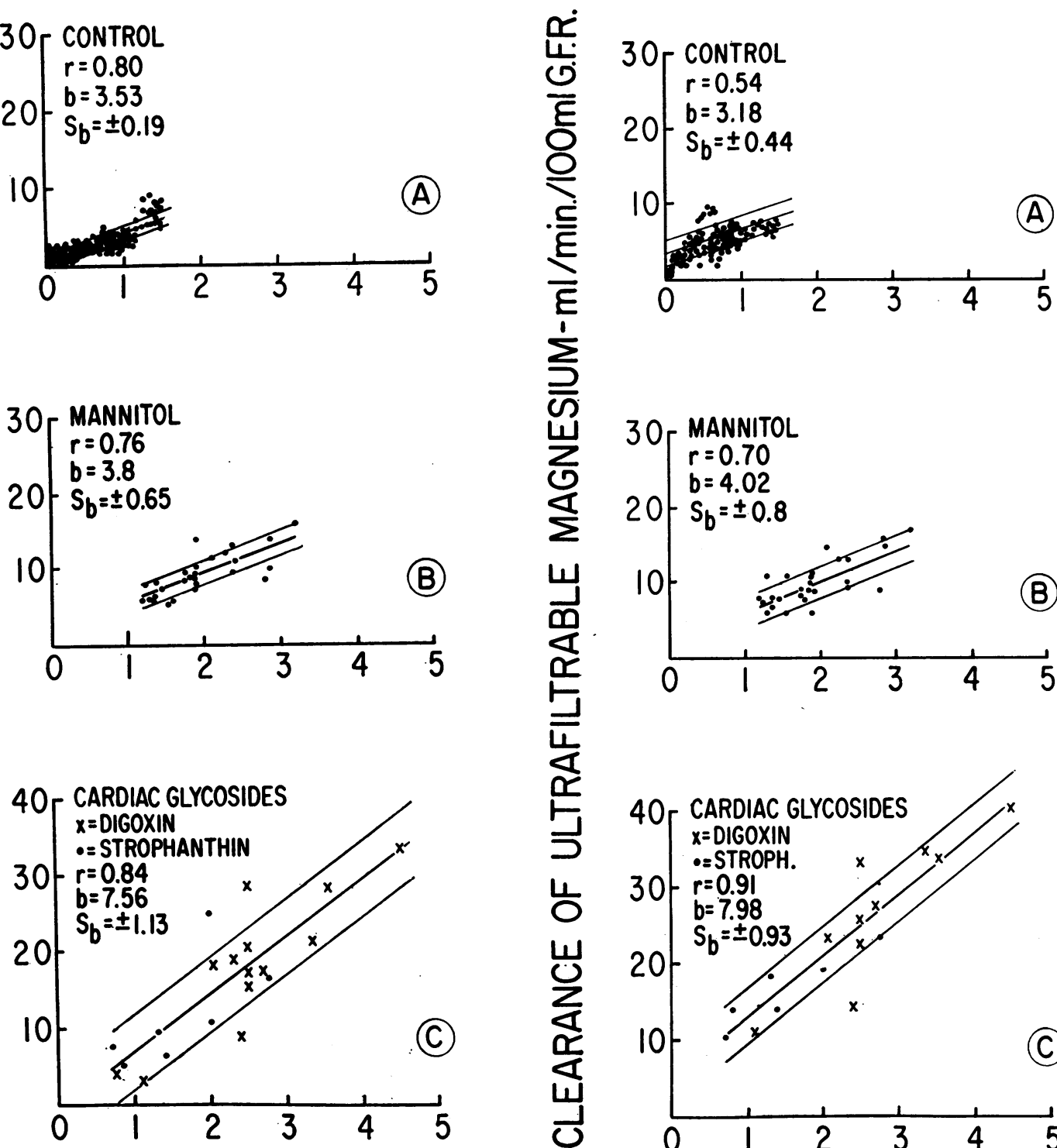

A)

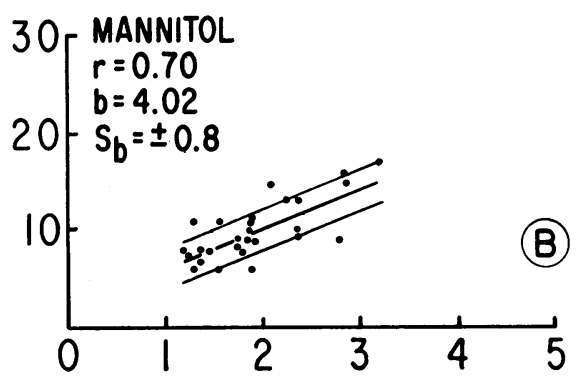

$\bigcup_{\mathrm{Na}} \mathrm{mM} / \mathrm{min} . / 100 \mathrm{ml}$ G.F.R.

Fig. 3. Clearance of ultrafiltrable calcium Per 100 ML GFR AS RELATED TO SODIUM EXCRETION (MMOLES PER MINUTE PER 100 ML GFR). One SD about the mean is represented by the light lines. $r=$ correlation coefficient; $b=$ slope of the regression curve; $S_{b}=$ the standard error of the slope. A) 197 control observations (see text). Many points are not illustrated because of overlapping. B) During mannitol diuresis (see text). C) During cardiac glycoside diuresis.

\pm 2.4 . The peak response to the administration of cardiac glycosides by the ipsilateral kidney generally occurred 100 to 120 minutes after the commencement of the unilateral intrarenal arterial in-

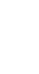


In 16 cardiac glycoside experiments in which the excretion of magnesium was measured, mean magnesium excretion during the premedication periods from both kidneys and from the noninfused control kidney during and after drug infusion was $3.3 \mu \mathrm{Eq}$ per minute \pm 1.6 . The mean peak excretory rate of magnesium from the infused kidney during the postdrug infusion period was $11.3 \mu \mathrm{Eq}$ per minute \pm 4.1 .

Effects of cardiac glycosides on clearances of calcium and magnesium relative to sodium excretion or clearance. Wesson (27) and Walser (28) have previously studied changes in clearance of these divalent cations in response to alterations in sodium excretion or clearance induced by intravenous infusion of nonionic osmotic agents, isotonic sodium chloride, or bicarbonate solutions and water loading. Since these investigators have calculated their data in different ways, we have computed our data to conform to each to facilitate comparison. Our "control" data represent the combined results from both kidneys during all premedication periods and from the contralateral kidney after infusion of the cardiac glycoside to the ipsilateral kidney. The ultrafiltrable fractions of calcium and magnesium were assumed to be $75 \%$ and $85 \%$ of their respective plasma concentrations (29). Although these estimates of the plasma ultrafiltrable fraction of either ion may not be entirely correct, the comparison of clearances of one kidney relative to the other will not be vitiated, as the composition of the plasma delivered to each kidney differed insignificantly since the intra-arterial infusion rate did not exceed 0.3 to $0.5 \mathrm{ml}$ per minute. In 197 control observations, representing the results from both kidneys before the infusion of medication, and from the contralateral kidney during and after the drug infusion, the ultrafiltrable calcium clearance ranged from 0.3 to $8.5 \mathrm{ml}$ per minute per $100 \mathrm{ml}$ GFR. Similarly, in the 130 periods in which magnesium was determined, the ultrafiltrable magnesium clearance ranged from 0 to $9.6 \mathrm{ml}$ per minute per $100 \mathrm{ml} \mathrm{GFR}$. The correlation between the clearances of these divalent cations and sodium excretion is shown in Figures $3 \mathrm{~A}$ and $4 \mathrm{~A}$. The slope of the regression curves (Figures $3 \mathrm{~A}$ and $4 \mathrm{~A}$ ) relating calcium and magnesium clearances to sodium excretion during these control periods is, respectively, 3.5 and 3.2 .
To compare the effects of natriuresis per se on the clearances of calcium and magnesium over a somewhat more extended range, observations were made in five additional experiments (27 clearance periods) in which $5 \%$ or $10 \%$ mannitol was infused intravenously. The slopes of the regression curves (Figures $3 \mathrm{~B}$ and $4 \mathrm{~B}$ ) are 3.8 and 4.0 for calcium and magnesium, respectively. These slopes do not prove to be significantly different from the slopes shown in Figures $3 \mathrm{~A}$ and $4 \mathrm{~A}$. The slopes of the curves for calcium and magnesium also do not appear to be significantly different. Wesson (27) reported that the slope of the regression curve relating the clearances of these divalent cations to sodium excretion during moderate urea diuresis was 3.2 for calcium and 3.0 for magnesium.

The relationship between the clearances of ultrafiltrable calcium and magnesium and sodium excretion at the height of the ipsilateral response to the cardiac glycoside is plotted in Figures 3C and $4 \mathrm{C}$. The slope of the curve for calcium is 7.6 , and that for magnesium is 8.0. These slopes are significantly different $(p<0.001)$ from those depicted in Figures 3A, 3B, 4A, and 4B. Again, the difference between the calcium and magnesium curves is not significant.

In studies in which diuresis in the dog was promoted by water loading and by infusions of isotonic sodium chloride and bicarbonate solutions and nonionic osmotic agents, Walser depicted total calcium clearance as a linear function of sodium clearance with a slope approximating 0.5. In our study the slope of the curve relating total calcium clearance to sodium clearance during 197 control periods as well as mannitol diuresis was computed to be $0.42 \pm 0.02^{2} \quad(r=0.87)$. After cardiac glycoside infusion, the slope of the curve relating the clearances of total calcium to sodium from the ipsilateral kidney was computed to be $0.88 \pm 0.12^{2} \quad(r=0.87)$. The difference in the slopes of these curves is significant $(p<$ 0.001).

Effects of cardiac glycosides on inorganic phosphate excretion and glucose reabsorption. As illustrated in Figure 1, the rate of excretion of inorganic phosphate from the experimental kidney remained unchanged during the initial period in

\footnotetext{
2 Standard error of the slope.
} 

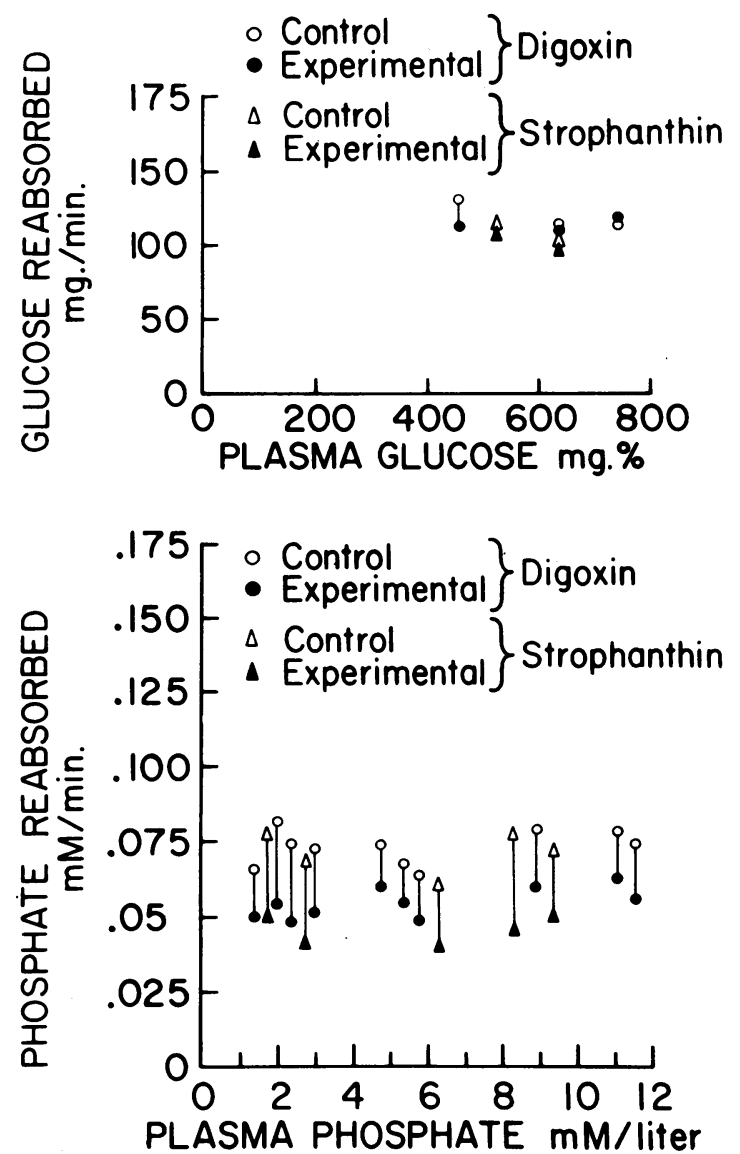

Fig. 5. EFFECtS of UNilateral RENAL ARTERIAL ADMINISTRATION OF CARDIAC GLYCOSIDES ON MAXIMAL TRANSPORT OF PHOSPHATE AND GLUCOSE. The glomerular filtration rates were similar in both experiments.

which digoxin was being infused into the renal artery. Thereafter, progressive increases in inorganic phosphate excretion were observed until a maximal response was noted 80 to 100 minutes after the commencement of the infusion. In 11 experiments the mean rate of excretion of inorganic phosphate from one kidney during the control period was $4.2 \mu$ moles $\mathrm{P}$ per minute \pm 3.12. The mean peak excretory rate from the infused kidney was $18.2 \mu$ moles $\mathrm{P}$ per minute \pm 4.26. The difference between these means was statistically significant $(\mathrm{p}<0.001)$. Phosphaturia did not occur when mercurial diuretic agents were infused directly into the renal artery (three experiments). In nine additional experiments in which either $5 \%$ or $10 \%$ mannitol was infused intravenously, no significant changes in in- organic phosphate excretion were observed. In experiments carried out under protocol $\mathrm{B}$, the net tubular reabsorptive capacity for inorganic phosphate following the intrarenal arterial administration of cardiac glycosides was depressed 20 to $52 \%$ from the control values, with an average decrease of $33 \%$. Immediately after termination of the glycoside infusion, and while the sustaining solution containing phosphate buffer was continued, the intravenous administration of sufficient glucose to produce and maintain glycosuria did not reveal any differences in maximal transport $(\mathrm{Tm})$ of glucose measurements bilaterally. When glucose was infused, the rate of inorganic phosphate reabsorption in each kidney decreased. However, the rate of inorganic phosphate reabsorption in the experimental kidney, to which cardiac glycoside had been administered via the renal artery, still remained less than that for the noninfused control kidney. The results in one experiment utilizing digoxin are recorded in $\mathrm{Ta}$ ble II. Maximal transport of phosphate $\left(\mathrm{T}_{\mathrm{PO}_{4}}\right)$ and of glucose $\left(\mathrm{Tm}_{\mathrm{G}}\right)$ measurements in one other experiment in which digoxin was administered and in one utilizing strophanthin are illustrated in Figure 5.

In two similar studies using mercurial diuretics instead of cardiac glycosides, no effects on either $\mathrm{Tm}_{\mathrm{PO}_{4}}$ or $\mathrm{Tm}_{\mathrm{G}}$ were observed. No alterations in $\mathrm{Tm}_{\mathrm{PO}_{4}}$ were found in four additional experiments in which mercurial diuretic was administered intravenously. Similarly in two experiments, intravenously administered chlorothiazide failed to alter $\mathrm{Tm}_{\mathrm{PO}_{4}}$. These latter two experiments were carried out after several attempts in which the drug was infused into the renal artery failed to evoke an ipsilateral diuresis. This experience has been noted by Kahn (30).

\section{Discussion}

Effects of cardiac glycosides on calcium and magnesium excretion. The present series of experiments confirms the previous observations of both Walser and Wesson that the excretion of calcium and magnesium is directly related to sodium excretion. If the different methods and conditions we employed are taken into consideration, the slopes of our curves relating calcium and magnesium clearances to either sodium excretion 
or sodium clearance under control conditions and during osmotic diuresis agree very well with those observed by Wesson and Walser. Both investigators suggested that their results supported the view that these divalent cations compete with sodium for some portion of the tubular reabsorptive mechanism. Such a conclusion implies that the tubular processes involved in transport of these ions are geared to maintain a relatively constant urinary concentration ratio of ionic calcium and magnesium to sodium. However, the present studies indicate that in response to the administration of cardiac glycosides, the clearance of both calcium and magnesium relative to either sodium excretion or sodium clearance is markedly enhanced. This suggests to us that cardiac glycosides inhibit some phase of calcium and magnesium transport not shared by sodium. It is possible that this superimposed inhibition of calcium and magnesium transport reflects a change in the ability of some component or components of the luminal membrane of tubular cells to bind these divalent ions in the usual proportions. Such an effect could explain the observed shift in urinary concentration ratios of these ions.

Other investigators have observed that calcium and magnesium excretion relative to sodium excretion can be sharply altered under a variety of diuretic conditions. Wesson $(27,31)$ noted enhanced calcium and magnesium excretion during hypertonic saline loading and intense osmotic and mercurial diuresis. We too have observed similar results in three experiments when a mercurial diuretic agent was infused into one renal artery. Reduced calcium excretion has been reported during diuresis following the administra-

TABLE II

Effect of digoxin on maximal transport of phosphate*

\begin{tabular}{|c|c|c|c|c|c|c|c|c|c|c|c|c|}
\hline \multirow[b]{2}{*}{ Time } & \multicolumn{2}{|c|}{$\mathbf{V}$} & \multicolumn{2}{|c|}{ GFR } & \multirow[t]{2}{*}{ PPO4 } & \multicolumn{2}{|c|}{ UPO\&V } & \multicolumn{2}{|c|}{ Reabsorbed $\mathrm{PO}_{4}$} & \multirow[t]{2}{*}{$\mathrm{Pa}$} & $\mathrm{UaV}$ & Reabsorbed G \\
\hline & $\mathrm{C}+$ & $\mathrm{E} \dagger$ & C & $\mathbf{E}$ & & C & $\mathbf{E}$ & C & $\mathrm{E}$ & & C & C \\
\hline $\min$ & \multicolumn{2}{|c|}{$m l / \min$} & \multicolumn{2}{|c|}{$m l / \min$} & $\mu$ moles $/ m l$ & \multicolumn{2}{|c|}{$\mu m o l e s / \min$} & \multicolumn{2}{|c|}{ 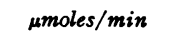 } & $m g / m l$ & $m g / \min$ & $m g / \min$ \\
\hline $\begin{array}{r}0-10 \\
10-20 \\
20-30\end{array}$ & $\begin{array}{l}0.60 \\
0.35 \\
0.35\end{array}$ & $\begin{array}{l}0.60 \\
0.35 \\
0.35\end{array}$ & $\begin{array}{l}49.6 \\
43.0 \\
42.0\end{array}$ & $\begin{array}{l}41.5 \\
45.6 \\
41.0\end{array}$ & $\begin{array}{l}1.04 \\
1.04 \\
1.07\end{array}$ & $\begin{array}{l}1.9 \\
1.1 \\
0.7\end{array}$ & $\begin{array}{l}2.4 \\
1.3 \\
0.6\end{array}$ & $\begin{array}{l}49.5 \\
43.1 \\
44.3\end{array}$ & $\begin{array}{l}40.6 \\
46.1 \\
43.3\end{array}$ & & & \\
\hline
\end{tabular}

Infusion of $1.0 \mathrm{mg}$ digoxin $(0.05 \mathrm{mg}$ per $\mathrm{kg})$ dissolved in $1.0 \mathrm{ml} 95 \%$ ethanol and $14.0 \mathrm{ml}$ isotonic sodium chloride at $0.5 \mathrm{ml}$ per minute into the renal artery of the experimental kidney

$\begin{array}{llllllllll}30-50 & 0.35 & 0.28 & 46.0 & 44.0 & 1.07 & 0.3 & 0.3 & 48.8 & 46.7\end{array}$

Infusion of drug completed at 60 minutes

$\begin{array}{llllllllll}50-70 & 0.58 & 0.50 & 47.7 & 47.5 & 1.07 & 0.9 & 1.3 & 49.7 & 49.3 \\ 70-85 & 0.72 & 1.80 & 44.0 & 41.6 & 1.07 & 1.9 & 6.1 & 42.1 & 35.5\end{array}$

Intravenous infusion of 0.25 mmole per minute phosphate as buffered sodium phosphate, $\mathrm{pH} 7.4$

$\begin{array}{rrrrrrrrrr}85-105 & 0.65 & 3.25 & 48.8 & 38.2 & 1.20 & 3.4 & 12.3 & 55.1 & 34.3 \\ 105-115 & 0.80 & 4.35 & 50.2 & 40.4 & 1.74 & 20.8 & 31.5 & 66.4 & 38.9 \\ 115-125 & 0.98 & 4.95 & 46.5 & 44.4 & 1.82 & 20.0 & 48.1 & 64.0 & 31.8 \\ 125-135 & 1.68 & 5.40 & 43.0 & 45.6 & 2.10 & 34.0 & 62.0 & 57.0 & 34.0\end{array}$

Intravenous infusion of 1.0 mmole per minute phosphate as buffered sodium phosphate, $\mathrm{pH} 7.4$

$\begin{array}{llllllllll}135-155 & 2.55 & 6.25 & 43.0 & 43.2 & 3.80 & 104 & 131 & 59.0 & 26.0 \\ 155-165 & 3.35 & 7.80 & 41.4 & 40.5 & 5.80 & 171 & 202 & 61.0 & 34.0 \\ 165-175 & 3.95 & 8.70 & 45.0 & 43.5 & 6.80 & 217 & 244 & 76.0 & 48.0 \\ 175-185 & 4.0 & 8.60 & 45.2 & 42.5 & 7.30 & 256 & 276 & 74.0 & 35.0\end{array}$

185-215 Intravenous infusion of $5.0 \mathrm{~g}$ glucose followed by sustaining dose of $1.0 \mathrm{~g}$ per minute; phosphate infusion maintained

$\begin{array}{rrrrrrrrrrrrrrr}215-225 & 12.2 & 17.0 & 42.6 & 44.8 & 11.7 & 480 & 494 & 45.0 & 30.0 & 7.0 & 208 & 214 & 90 & 100 \\ 225-235 & 10.1 & 15.0 & 42.0 & 44.2 & 11.5 & 435 & 482 & 48.0 & 25.0 & 6.0 & 162 & 176 & 90 & 95 \\ 235-245 & 9.0 & 15.2 & 42.7 & 44.4 & 11.6 & 443 & 488 & 53.0 & 26.0 & 6.0 & 159 & 163 & 97 & 105\end{array}$

${ }^{*} \mathrm{~V}=$ rate of urine flow $; \mathrm{GFR}=$ glomerular filtration rate; $\mathrm{P}_{\mathrm{PO}_{4}}$ and $\mathrm{P}_{\mathrm{G}}=$ plasma phosphate and glucose, respec-

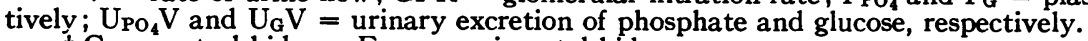

$\dagger \mathrm{C}=$ control kidney; $\mathrm{E}=$ experimental kidney. 
tion of chlorothiazide and related compounds $(32,33)$. Bronner and Thompson (34) have interpreted dissimilar patterns of transtubular fluxes of sodium and calcium as favoring some differences in the manner in which these ions are handled.

The similarity in response of both calcium and magnesium to the administration of cardiac glycosides suggests inhibition of two independent reabsorptive systems simultaneously or, more likely, inhibition of a common pathway. The studies of Samiy and his co-workers (29) support the view that calcium and magnesium compete for a common reabsorptive mechanism.

Effect of cardiac glycosides on inorganic phosphate and glucose reabsorption. The enhanced urinary excretion of inorganic phosphate following the injection of cardiac glycosides is chiefly attributable to decreased reabsorption of inorganic phosphate. The series of experiments in which phosphate loading permitted independent evaluation of $\mathrm{Tm}$ phosphate in each kidney reinforces this view. The inhibition of phosphate transport was unique to the diuresis that followed cardiac glycoside administration, and we did not observe such inhibition with other agents such as mannitol (nine experiments), mercurials (seven experiments), and chlorothiazide (two experiments).

Mudge, Foulks, and Gilman (35), Wesson and Anslow (36), and Wesson (27) have shown little or no effects on phosphate excretion during urea diuresis. Similar observations were recorded by Seldin and Tarail (37) when mannitol was used. Huffman, Schwartz, and Barry (38) failed to note any change in phosphate excretion during water diuresis. Farnsworth (39) observed no changes in phosphate excretion following Mercupurin diuresis in man. Wesson (31), however, noted phosphaturia in four of seven experiments in which Mercurin was injected intravenously. $\mathrm{He}$ stated that these data were of borderline significance $(p \cong 0.1)$ with respect to establishing an effect of Mercurin on phosphate excretion. Examination of his Figure 2 shows two experiments in which an increase in phosphate excretion occurring in the first hour was followed by a decrease and then a subsequent rise. Data on plasma phosphate concentrations during these long experiments unfortunately were not available, which makes it difficult to compare his data with ours. In our experience the intrarenal arterial administration of a mercurial diuretic was not followed by ipsilateral phosphaturia. Moreover, no change in $\mathrm{Tm}_{\mathrm{PO}_{4}}$ was observed in two mercurial diuretic experiments in which stepwise phosphate loading was accomplished.

Glucose infusions clearly lowered $\mathrm{Tm}_{\mathrm{PO}_{4}}$ as previously reported by Pitts and Alexander (40). In buman subjects, Gershberg (41) has reported that about $20 \%$ of the filtered phosphate is reabsorbed by the same process as glucose, and that reabsorption of this fraction of phosphate is under parathyroid control. Although in the present studies there were no differences in $\mathrm{Tm}_{\mathrm{G}}$ for both kidneys after the administration of cardiac glycosides, $\mathrm{Tm}$ phosphate of the glycoside-treated kidney remained less than that for the control kidney. This finding suggests that cardiac glycosides may affect renal tubular excretion of inorganic phosphate differently than glucose, since the infusion of large quantities of glucose did not abolish the differences in $\mathrm{Tm}_{\mathrm{PO}_{4}}$ in the two kidneys.

Inasmuch as we are unable to show a reduction in $\mathrm{Tm}$ glucose following cardiac glycoside infusion, it is conceivable that glucose transport by the tubular cells in vivo, unlike that in the intestinal mucosa $(16,17)$, is not dependent on monovalent cation transport. It is possible, however, that the dose of cardiac glycoside employed in these studies failed to inhibit cation transport sufficiently to affect glucose transport to a measurable degree. We do not believe that a meaningful selection between these two alternatives can be made on the basis of our data or that from the literature.

In two studies in which mercurial diuretics were infused instead of cardiac glycosides, Tm glucose was not depressed. This finding is in agreement with that of Handley, Telford, and La Forge (42) in the dog, of McDonald and Miller (43) in man, and of others (44-46) but is in conflict with that of Weston and associates (47), who noted a 40 to $80 \%$ reduction in Tm glucose following intravenous administration of Mercuzanthin or Thiomerin.

It might be anticipated that the effects of cardiac glycosides on sodium-potassium transport would 
reduce the transtubular potential difference and thereby inhibit phosphate reabsorption. Giebisch (48), however, failed to observe a change in potential difference in Necturus tubules when the concentration of ouabain in the perfusate was less than $10^{-4}$ mole per $L$. In our experiments, a maximal concentration of cardiac glycosides in the order of $10^{-5}$ mole per $L$ could have been achieved had the entire dose been retained in a single kidney. This degree of localization appears unlikely. Interestingly, Giebisch did note reductions in transtubular potentials when chlormerodrin was added to the perfusate at a concentration of 10 to $20 \mu \mathrm{g}$ per $\mathrm{ml}$. It is our view, therefore, that the phosphaturic effect of the cardiac glycosides, at the dose levels used in our experiments, cannot be attributed to alterations in transtubular potential differences.

The inorganic phosphate transport system in everted loops of rat small intestine in vitro has been shown to require sodium to maintain a concentration difference between serosal and mucosal fluids (17). However, some data suggest that inorganic phosphate transport in the kidney does not depend entirely on cation transport. Morrison, Buckalew, Miller, and Lewis (49) have observed in the dog that $\mathrm{Tm}_{\mathrm{PO}_{4}}$ is unaffected by long-term potassium depletion. Similarly, the stability of $\mathrm{Tm}_{\mathrm{PO}_{4}}$ in the face of wide alterations in sodium and potassium excretion by other diuretic agents, as herein described, as well as changes in phosphate reabsorption effected by such agents as glucose, phlorizin, and parathyroid hormone, indicates that there may be several factors that independently influence renal tubular transport of phosphate.

\section{Summary}

Cardiac glycosides, when injected into one renal artery, directly affect renal tubular function. In contrast to the proportionate increases in excretion or clearance or both of calcium, magnesium, and sodium when diuresis is evoked by infusion of isotonic sodium chloride or various nonionic osmotic agents, the ensuing diuretic response to cardiac glycosides is associated with disproportionate augmentation in the clearance of these divalent cations relative to that for sodium. This dissociation supports the view that some phase of calcium and magnesium reabsorption by the kidney is handled by a process not shared with sodium.

Cardiac glycosides have also been found to increase the urinary excretion of inorganic phosphate, chiefly by inhibiting tubular reabsorption of inorganic phosphate. No change in the maximal transport $(\mathrm{Tm})$ of glucose was observed at the dose levels studied. It is suggested that glucose transport by renal tubular cells may be independent of cation transport. In experiments in which the effects of mercurial diuretics were studied, neither phosphaturia nor alterations in $\mathrm{Tm}$ phosphate or Tm glucose were observed.

\section{Acknowledgments}

The authors are grateful for the devoted technical assistance provided by Miss Marion E. Garner and Mr. Hugh L. Grogan.

\section{References}

1. Schatzmann, H. J. Herzglykoside als Hemmstoffe für den aktiven Kalium- und Natriumtransport durch die Erythrocytenmembran. Helv. physiol. pharmacol. Acta 1953, 11, 346.

2. Kahn, J. B., Jr., and G. H. Acheson. Effects of cardiac glycosides and other lactones, and of certain other compounds, on cation transfer in human erythrocytes. J. Pharmacol. exp. Ther. 1955, $115,305$.

3. Solomon, A. K., T. J. Till III, and G. L. Gold. The kinetics of cardiac glycoside inhibition of potassium transport in human erythrocytes. J. gen. Physiol. 1956-57, 40, 327.

4. Glynn, I. M. The action of cardiac glycosides on sodium and potassium movements in human red cells. J. Physiol. (Lond.) 1957, 136, 148.

5. Johnson, J. A. Influence of ouabain, strophanthidin and dehydrostrophanthidin on sodium and potassium transport in frog sartorii. Amer. J. Physiol. 1956, 187, 328.

6. Shreiber, S. S. Potassium and sodium exchange in the working frog heart. Effects of overwork, external concentrations of potassium and ouabain. Amer. J. Physiol. 1956, 185, 337.

7. Koefoed-Johnson, V. The effect of G-strophanthin (ouabain) on the active transport of sodium through the isolated frog skin (abstract). Acta physiol. scand. 1957, 42 (suppl. 145), 87.

8. Maizels, M., M. Remington, and R. Truscoe. The effects of certain physical factors and of the cardiac glycosides on sodium transfer by mouse ascites tumour cells. J. Physiol. (Lond.) 1958, 140, 61. 
9. Schatzmann, H. J., E. E. Windhager, and A. K. Solomon. Single proximal tubules of the Necturus kidney. II. Effect of 2,4-dinitrophenol and ouabain on water reabsorption. Amer. J. Physiol. 1958, 195, 570.

10. Hyman, A. L., W. E. Jacques, and E. S. Hyman. Observations on the direct effect of digoxin on renal excretion of sodium and water. Amer. Heart J. 1956, 52, 592.

11. Strickler, J. C., and R. H. Kessler. Direct renal action of some digitalis steroids. J. clin. Invest. 1961, 40, 311.

12. Orloff, J., and M. Burg. Effect of strophanthidin on electrolyte excretion in the chicken. Amer. J. Physiol. 1960, 199, 49.

13. Cade, J. R., R. J. Shalhoub, M. Cannessa-Fischer, and R. F. Pitts. Effect of strophanthidin on the renal tubules of dogs. Amer. J. Physiol. 1961, 200, 373.

14. Burg, M. B., and J. Orloff. Effect of strophanthidin on electrolyte content and PAH accumulation of rabbit kidney slices. Amer. J. Physiol. 1962, 202, 565.

15. Wolff, J. Thyroidal iodide transport. I. Cardiac glycosides and the role of potassium. Biochim. biophys. Acta (Amst.) 1960, 38, 316.

16. Csáky, T. Z., H. G. Hartzog III, and G. W. Fernald. Effect of digitalis on active intestinal sugar transport. Amer. J. Physiol. 1961, 200, 459.

17. Harrison, H. E., and H. C. Harrison. Sodium, potassium, and intestinal transport of glucose, L-tyrosine, phosphate, and calcium. Amer. J. Physiol. 1963, 205, 107.

18. Niedergerke, $R$. The rate of action of calcium ions on the contraction of the heart. J. Physiol. (Lond.) 1957, 138, 506.

19. Smith, H. W., N. Finkelstein, L. Aliminosa, B. Crawford, and $M$. Graber. The renal clearances of substituted hippuric acid derivatives and other aromatic acids in dog and man. J. clin. Invest. 1945, 24, 388.

20. Kinglsey, G. R., and O. Robnett. Further studies on a new dye method for the direct photometric determination of calcium. Amer. J. clin. Path. 1958, 29, 171.

21. Neill, D. W., and R. A. Neely. The estimation of magnesium in serum using titan yellow. J. clin. Path. 1956, 9, 162.

22. Zettner, A., and D. Seligson. Application of atomic absorption spectrophotometry in the determination of calcium and serum. Clin. Chem., in press.

23. Willis, J. B. Determination of calcium and magnesium in urine by atomic absorption spectroscopy. Analyt. Chem. 1961, 33, 556.

24. Cotlove, E., H. V. Trantham, and R. L. Bowman. An instrument and method for automatic, rapid, accurate, and sensitive titration of chloride in biologic samples. J. Lab. clin. Med. 1958, 51, 461.
25. Fiske, C. H., and Y. Subbarow. The colorimetric determination of phosphorus. J. biol. Chem. 1925, $66,375$.

26. Nelson, N. A photometric adaptation of the Somogyi method for the determination of glucose. J. biol. Chem. 1944, 153, 375.

27. Wesson, L. G., Jr. Magnesium, calcium, and phosphate excretion during osmotic diuresis in the dog. J. Lab. clin. Med. 1962, 60, 422.

28. Walser, $M$. Calcium clearance as a function of sodium clearance in the dog. Amer. J. Physiol. 1961, 200, 1099.

29. Samiy, A. H. E., J. L. Brown, D. L. Globus, R. H. Kessler, and D. D. Thompson. Interrelation between renal transport systems of magnesium and calcium. Amer. J. Physiol. 1960, 198, 599.

30. Kahn, M. Personal communication.

31. Wesson, L. G., Jr. Organic mercurial effects on renal tubular reabsorption of calcium and magnesium and on phosphate excretion in the dog. J. Lab. clin. Med. 1962, 59, 630.

32. Walser, M., and J. R. Trounce. The effect of diuresis and diuretics upon the renal tubular transport of alkaline earth cations (abstract). Biochem. Pharmacol. 1961, 8, 157.

33. Poutsiaka, J. W., H. Madissow, L. G. Millstein, and J. Kirpan. Effects of benzydroflumethiazide (naturetin) on the renal excretion of calcium and magnesium by dogs. Toxicol. appl. Pharmacol. 1961, 3, 455.

34. Bronner, F., and D. D. Thompson. Renal transtubular flux of electrolytes in dogs with special reference to calcium. J. Physiol. (Lond.) 1961, 157, 232.

35. Mudge, G. H., J. Foulks, and A. Gilman. Effect of urea diuresis on renal excretion of electrolytes. Amer. J. Physiol. 1949, 158, 218.

36. Wesson, L. G., Jr., and W. P. Anslow, Jr. Excretion of sodium and water during osmotic diuresis in the dog. Amer. J. Physiol. 1948, 153, 465.

37. Seldin, D. W., and R. Tarail. Effect of hypertonic solutions on metabolism and excretion of electrolytes. Amer. J. Physiol. 1949, 159, 160.

38. Huffman, R. M., F. D. Schwartz, and K. G. Barry. Phosphorus "wash-out" during water diuresis (abstract). Clin. Res. 1962, 10, 249.

39. Farnsworth, E. B. Clearance of inulin, Diodrast, chloride and phosphate under mercurial diuresis. Amer. J. Med. 1946, 1, 246.

40. Pitts, R. F., and R. S. Alexander. The renal reabsorptive mechanism for inorganic phosphate in normal and acidotic dogs. Amer. J. Physiol. 1944, $142,648$.

41. Gershberg, H. Renal effects of parathyroid extract. Trans. N. Y. Acad. Sci. (series II) 1962, 24, 273.

42. Handley, C. A., J. Telford, and M. La Forge. Xanthine and mercurial diuretics and renal tubular 
transport of glucose and p-aminohippurate in the dog. Proc. Soc. exp. Biol. (N. Y.) 1949, 71, 187.

43. McDonald, R. K., and J. H. Miller. Effect of mercury on renal tubular transfer of p-aminohippurate and glucose in man. Proc. Soc. exp. Biol. (N. Y.) 1949, 72, 408.

44. Letteri, J. M., J. A. Bard, and L. G. Wesson, Jr. Effect of mercurial diuretics on maximal rate of renal glucose transport in man. Proc. Soc. exp. Biol. (N. Y.) 1962, 110, 176.

45. Barrett, M. J. Chronic and acute effects of mercuhydrin and thiomerin on renal tubular function in the dog. J. Pharmacol. exp. Ther. 1950, 100, 502.

46. Handley, C. A., R. B. Sigafoos, and M. La Forge. Proportional changes in renal tubular reabsorption of dextrose and excretion of p-aminohippurate with changes in glomerular filtration. Amer. J. Physiol. 1949, 159, 175.

47. Weston, R. E., J. Grossman, I. S. Edelman, D. J. W. Escher, L. Leiter, and L. Hellman. Renal tubular action of diuretics II. Effects of mercurial diuresis on glucose reabsorption (abstract). Fed. Proc. 1949, 8, 164.

48. Giebisch, G. Measurements of electrical potential differences in single nephrons of the perfused Necturus kidney. J. gen. Physiol. 1961, 44, 659.

49. Morrison, A. B., V. M. Buckalew, Jr., R. Miller, and J. D. Lewis. The reabsorption of phosphate by the kidney in potassium-deficient dogs. (abstract). J. clin. Invest. 1960, 39, 1014.

\section{SPECIAL NOTICE TO SUBSCRIBERS}

Post Offices will no longer forward the Journal when you move.

Please notify The Journal of Clinical Investigation, Business Office, 10 Stoughton Street, Boston, Mass. 02118, at once when you have a change of address, and do not omit the Zip Code number. 